\title{
ポンプの最小差圧変流量制御のエネルギー消費量子測 PREDICTION OF ENERGY CONSUMPTION IN VWV SYSTEM BY MINIMUM DIFFERENTIAL PRESSURE CONTROL
}

\author{
富權 英 介*1
}

Eisuke TOGASHI

\begin{abstract}
The error of a conventional simple pump model that approximates the resistance of a piping network using a linear or quadratic equation of flow rate was evaluated. A new water circuit model that can easily construct a parallel flow network of free depth without convergence calculation was developed. It is shown that due to a non-uniform distribution of load, an error of several tenths in energy prediction should occur in the conventional simple model. The magnitude of this error could be higher than the error that is influenced by various parameters which many previous programs have attempted to precisely represent.
\end{abstract}

Keywords : Pump, Circuit network, Non-uniform load, Energy consumption, Simulation ポンプ，回路網，負荷の偏在，エネルギー消費，シミュレーション

\section{1. はじめに}

熱源機の高効率化が大きく進み、効率向上が飽和しつつある中、 熱搬送に費やすエネルギーの削減が相対的に重要性を増している。 搬送系のエネルギーを検討寸る上で困難な点は、ポンプやファンな どの搬送機器の運転点が、配管やダクト全体の回路の構成や各部位 の運転状況に影響されて変化するという点にある。従って、このよ うな熱搬送システムのエネルギー消費を正しく予測するためには、 配管やダクト回路網の各節点の圧力や各流路の流量を解く必要があ る。一方で、既存の一般的な建築エネルギーシミュレーションプロ グラムでは、ポンプの必要差圧が流量または流量の二乗に比例する という仮定をおき、単一の抵抗係数で回路網の抵抗特性を表現する。 このような仮定は計算が容易であり、末端差圧一定制御や推定末端 差圧制御の場合には大きな誤差は生じないと予想される。しかし最 小差圧変流量制御1)のように、限界まで差圧を下げて省エネルギー 化を図る方式で同じ仮定を用いることは、大きな誤差を生む危険性 を持つ。回路網に含まれる全ての流路における負荷が均等に増減を 繰り返すのであれば良いが、現実の建物がそうであるように負荷が 偏在する場合には、ポンプの必要差圧は単純に流量の一次式や二次 式では表現できないためである。そこで本研究では、まず、複雑な 配管回路網を収束計算せずに簡易に解ける新たな回路網モデルを開 発する。さらに本モデルを用いて基準オフィスビルの冷温水配管回 路網をモデル化する。熱負荷計算にもとづく冷温水量を入力するこ とで、負荷が偏在する時の正確なポンプの運転点を計算し、従来の 簡易モデルを援用した場合に生じうる誤差を定量的に評価する。

\section{2. 既存のシミュレーションにおける水搬送系の計算法}

建築のエネルギーシミュレーションを行う場合、熱負荷計算を行 うかあるいは境界条件として熱負荷が与えられることなどにより、 二次側の熱負荷 $Q_{s c d}[\mathrm{~kW}]$ は、水搬送系の計算に先立って与えられる ことが多い。同様に、二次側還水温 $T_{w, r t}[\mathrm{~K}]$ も、二次側でコイル計算 を行うか、あるいは境界条件として温度差が与えられることなどに より、既知である。従って、ポンプによる循環水量 $V_{w}\left[\mathrm{~m}^{3} / \mathrm{s}\right]$ は式(1) で計算できる。ただし $c \rho_{w}\left[\mathrm{~kJ} /\left(\mathrm{m}^{3} \cdot \mathrm{K}\right)\right]$ は循環水の体積比熱、 $T_{w, s p}[\mathrm{~K}]$ は二次側往水温である。このため、既存のシミュレーションプログ ラムのほとんどは、二次側循環水量 $V_{w}$ を基礎に計算を行っている。 $Q_{s c d}=c \rho_{w} V_{w}\left(T_{w, s p}-T_{w, r t}\right)$

最も簡単な計算方法は、ポンプによる昇圧を明示的に取り扱わず、 $V_{w}$ のみを手掛かりに消費電力を推定する方法である。この方法では、 ポンプ消費電力 $W[\mathrm{~kW}$ を式(2)に示寸ような特性式で直接に推定す る。ただし、 $W_{N}[\mathrm{~kW}]$ は定格消費電力、 $C_{m}$ は特性係数である。 HASP/ACSS ${ }^{2}$ や Energy Plus ${ }^{3}$ の簡易ポンプモデル (Variable Speed Pump モデル）ではこの方法が採用されている。

$$
W=W_{N} \sum_{m=0}^{M}\left(C_{m} V_{w}^{m}\right)
$$

式(2)の方法は簡便である一方で、ポンプの特性や二次側配管網の 特性はすべて特性係数 $C_{m}$ によって表現されるため、機器の選定の 良否などの細かな検討はできない。そこで、何らかの方法でポンプ に求められる差圧 $\Delta P[\mathrm{kPa}]$ を推定し、これを用いて式(3)の理論式か らポンプ消費電力 $W$ を計算する方法がある。ただし $\eta_{p} 、 \eta_{M} 、 \eta_{I n v}$ は 
それぞれ、ポンプ効率、モーター効率、インバータ効率であり、こ れらの積は総合効率と呼ばれる。

$$
W=\frac{\Delta P \cdot V_{w}}{\eta_{p} \cdot \eta_{M} \cdot \eta_{I n v}}
$$

例えば Energy Plus のポンプモデルの一つ（Dynamic Pump Pressure Head モデル）では、 $\Delta P$ を二次側の個別の流路モデルが出力する圧 力損失の合算值として求めている ${ }^{3)}$ 。しかし本来、流路の圧力損失 は回路に含まれるポンプや他の流路との相互影響の中で決定するた め、独立に計算可能な值ではない。従って、各流路モデルにおいて 何かしらの仮定をおいて他の機器からの干渉を無視することで独立 に圧力損失を計算している。

複雑な二次側回路網を巨大な単一の抵抗と捉えて式(4)で二次側 圧力損失 $\Delta P$ を推定する方法もある。ただし $P_{0}[\mathrm{kPa}]$ は実揚程であ る。ここで、ポンプの PQ 特性を式(5)に示すように循環水量 $V_{w}$ の関 数として表現すれば、式(4)と式(5)を連成することでポンプの運転点 が定まるため、ポンプの特性を計算結果に反映することができる。 例えば LCEM ツールでは式(4)に従ってポンプの必要差圧を求める 計算方法を「最小吐出圧制御」と呼んでいる ${ }^{4) 5}$ ) また、Energy Plus の Pressure-based Flow for Variable Speed Pumps モデルにおいても、 式(4)にもとづいて推定された圧力が一定の範囲内に維持されるよ うにポンプの回転数が計算される ${ }^{3)}$ 。

$$
\begin{aligned}
& \Delta P=a V_{w}^{2}+P_{0} \\
& \Delta P=f\left(V_{w}\right)
\end{aligned}
$$

上記の LCEM と Energy Plus のモデルが現実の如何なる制御方式 と対応しているかは明示されていないが、必要圧力が流量の二乗に 比例して減少するという式(4)の仮定は、負荷に応じて二次側の各流 路の流量が均等に減少する理想的な場合にのみ成立する。例えば特 定の流路の負荷が下がらない場合など、負荷が偏在するような場合 には二次側の圧力損失は式(4)のように二次式では減少しない。そこ で現実の推定末端差圧制御では、必要差圧が不足しないように式(6) に示すように一次式で二次側の圧力損失を推定するという方法をと ることがある。BEST ではこの方法を採用しているの。

$$
\Delta P=b V_{w}+P_{0}
$$

循環水量の増減に対して、二次側の圧力損失が線形か否かは各流 路の要求水量の組み合わせに依存するため、単に式(4)か式(6)を用い ても最小差圧変流量制御の場合の必要差圧の推定はできない。任意 の回路の正確な圧力損失を推定するためには、ポンプを含む全ての 流量と圧力の平衡状態を解く必要がある。このような厳密な方法で 回路網を計算するプログラムとしてはHVACSIM+(J)が挙げられる7)。

HVACSIM+(J)の循環水量計算の基礎式を式(7)と式(8)に示す。式 (7)は各節点における質量保存式であり、 $V_{l, k}$ は $k$ 番の節点から $l$ 番の 節点一流入する水量である。節点が接続されていない場合には $V_{l, k}$ $=0$ である。式 $(8)$ は $k$ 番の節点と $l$ 番の節点との間の圧力損失 $\Delta P_{l, k}$ を 表しており、 $R_{l, k}\left[\mathrm{kPa} /\left(\mathrm{m}^{3} / \mathrm{s}\right)^{2}\right]$ は抵抗係数である。これらの両式にポ ンプの基礎式(5)を加え、各節点の圧力 $P_{k}[\mathrm{kPa}]$ を未知数として連立 非線形代数方程式を解く。ただし、節点の 1 つは基準圧力となるた め、未知数は節点数 -1 である。

$$
\begin{aligned}
& 0=\sum_{k=0}^{K} V_{l, k} \\
& \Delta P_{l, k}=R_{l, k} V_{l, k}^{2}
\end{aligned}
$$

HVACSIM+(J)の方法は制御系の検討を目的として開発された経 緯もあり、最も厳密な方法である。一方で、非線形の連立代数方程 式を解く必要があるため、必ずしも求根が保証されておらず、計算 負荷も大きいという問題がある。この点は、安定的に高速に解を得 る必要があるエネルギーシミュレーションにおいては大きな問題で ある。歴史の時系列としては HVACSIM+(J)の完成以降に開発が開始 された LCEM、BEST、 Energy Plus において二次側の圧力損失の簡易 推定モデルが採用されたことも、この問題が一つの原因であると推 測できる。また搬送エネルギーに関する既往研究 8) 9) 10)11において も、通常は二次側の圧力損失については上記の簡易モデルと類似の 仮定をおく。しかし、特に最小差圧変流量制御においてこのような 簡易モデルを援用した場合に、二次側の負荷の偏在に起因してどれ だけの誤差が生じるのかについては、これまで定量的な評価はされ ていない。そこで本研究では、現実の多くの配管回路網に適用可能 で、かつ、収束計算を行わずに解析的に必要差圧が計算できる汎用 回路網モデルを開発する。また、本モデルを基準オフィスビルに適 用し、最小差圧変流量制御を行った場合の必要圧力を計算する。こ の結果を式(4)と式(6)に示される必要差圧の簡易推定モデルの計算 結果と比較することで、簡易モデルを援用することで生じる誤差の 大きさを定量的に評価する。

\section{3. 汎用配管回路網モデルの開発 \\ 3.1 モデルの構造}

本モデルの目的は、空調機やファンコイルユニットなど、回路網 に含まれる熱交換器のそれぞれにおいて必要な水量を確保するため に、ポンプに求められる圧力と水量を推測することである。ただし、 それぞれの熱交換器には、最大開度から全閉まで、なめらかに制御 が可能な二方弁が付属していると仮定する注1)。流量制御用の二方弁 の特性は、弁開度と流量との間の固有特性で表現でき、例えば先述 の HVACSIM+(J)のような動的シミュレーションプログラムではこ れらの特性も含めてモデル化を行うことで、PID 制御などの制御機 構の良否も検討可能としている。しかし、本研究の目的は HASP/ACSS や Energy Plus などと同じ年間のエネルギーシミュレー ションであるため、固有特性のモデル化は行わず、必要な水量が得 られるように理想的に弁開度が操作されて瞬時に抵抗係数が調整さ れるものとした。

現実の空調設備システムの配管回路網は分岐と合流を繰り返し、 非常に複雑であり、様々な種類がある。この様々な回路網に対して 共通の方法でシミュレーションが可能となるように、まず、Fig.1に 示すように回路網モデルを抽象的に表現した。このように抽象的に 表現すれば、複雑な回路網であっても、オブジェクト指向言語を用 いて入れ子状のモデルとして表現するができ、簡単にシミュレーシ ヨンを行うことができる。この詳細は次節に述べる。

この抽象モデルは、水が送られる節点 $N_{s p}$ と水が戻る節点 $N_{r t}$ を持 つ。両節点に挟まれた内部の回路網の構成は任意であるが、次の 2 つの機能を持つ必要がある。

\section{1）節点間の必要合計水量 $V_{t t l}\left[\mathrm{~m}^{3} / \mathrm{s}\right]$ を計算できる}

2）節点間の必要最小差圧 $\min \left\{\Delta P_{s-r}\right\}[\mathrm{kPa}]$ を計算できる

これらの 2 つの機能を持つ、最も単純な回路は Fig.2 に示す直列 回路である。 $R_{f i x}\left[\mathrm{kPa} /\left(\mathrm{m}^{3} / \mathrm{s}\right)^{2}\right]$ は空調機やメンテナンス用の二方弁な 
ど、運用中に変化しない固定抵抗である。 $R_{\text {ctrl }}$ は制御に必要な水量 調整のための二方弁であり可変抵抗である。この場合、 $V_{t t l}$ は空調機 の必要水量そのものである。また $\min \left\{\Delta P_{s-r}\right\}$ は式(9)で計算できる。 $\min \left\{\Delta P_{s-r}\right\}=V_{t t l}^{2}\left(R_{f i x}+R_{c t r l}\right)$

並列回路のモデルを Fig. 3 に示す。 $N$ 個の流路が並列に並ぶ回路 であり、並列な流路（以下、並列流路）の間も別の流路で接続され る(以下、接続流路)。各並列流路には Fig.1 の抽象回路網を接続で きる。即ち Fig.2 で示した直列回路が接続されても良いし、Fig.3で 示した並列回路が入れ子状に接続されても良い。並列回路の $V_{t t l}$ は 式(10)に示すように各並列流路の必要水量の合計である。また、最小 差圧は式(11)および式(12)で計算できる。抽象回路網の機能要求の前 提により、各並列流路の必要水量は得ることができる。これらの水 量を足し合わせれば、接続流路の水量が得られ、抵抗係数 $R_{s p, n}$ およ び $R_{r t, n}$ にもとづいて、それぞれの接続流路の抵抗值 $\Delta P_{\text {cnct }}$ が得られ る (式(12)）。この抵抗值 $\Delta P_{c n c t}$ と並列流路の抵抗值 $\Delta P_{n}$ を加算寸れ ば当該並列流路にとって必要な差圧が求まり、すべての並列流路の 内、最大の值が、並列回路全体として必要な最小差圧となる(式(11))。

$$
V_{t t l}=\sum_{n=0}^{N} V_{n}
$$

$\min \left\{\Delta P_{s-r}\right\}=\max \left\{\Delta P_{n}+\Delta P_{c n c t, n}\right\}$

$$
\Delta P_{\text {cnct }, n}=\sum_{m=0}^{n}\left\{\left(V_{t t l}-\sum_{l=0}^{m} V_{l-1}\right)^{2}\left(R_{s p, m}+R_{r t, m}\right)\right\}
$$

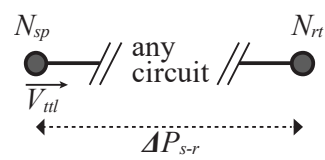

Fig.1 Abstract circuit model

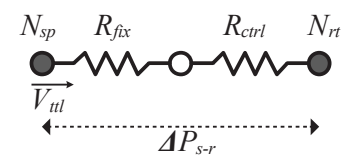

Fig.2 Series flow model

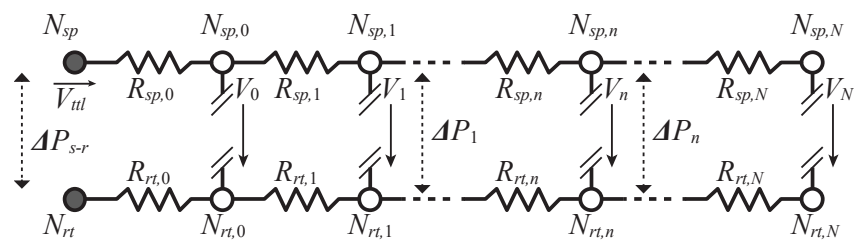

Fig.3 Parallel flow model

上記は、回路内のすべての二方弁の開度が最適化され、最小の差 圧で送水が可能となることを前提とした、最小差圧変流量制御注2)の 場合の計算法である。例えば現実の建物で、より採用が多い末端差 圧一定制御を計算する場合には Fig.3 で $\Delta P_{N}=$ const とすれば同じ方 法で解ける。なお、吐出圧一定制御や推定末端差圧制御の場合には、 そもそも本手法のような回路網モデルは不要である。

エネルギー消費予測を問題とするのであれば上記の方法で十分で あるが、HVACSIM+(J)のように制御検討をする場合には入力と出力 が逆転する。即ち、 $N_{s p}$ と $N_{r t}$ の差圧と各制御用二方弁の抵抗係数が 与えられた場合に、それぞれの空調機にどれだけの水量が流れるか を予測する問題である。この場合には上記の 2 つの機能に加え、

3）節点間の合成抵抗係数 $R_{c m b}\left[\mathrm{kPa} /\left(\mathrm{m}^{3} / \mathrm{s}\right)^{2}\right]$ を計算できる

という機能を持たせれば良い。Fig.2の直列回路の場合には、2つ の抵抗係数 $R_{f i x}$ と $R_{c t r l}$ を加算すれば $R_{c m b}$ が求められる。Fig.3 の並列 回路の場合には、最遠端から順に直列回路と並列回路の抵抗係数の
合成の計算を繰り返す。即ち、並列流路の抵抗係数を $R_{n}$ とおき、ま ず、 $R_{s p, N} 、 R_{r t, N} 、 R_{n}$ を足し合わせて最遠端の抵抗係数を合成する。こ の合成抵抗係数と $R_{N-1}$ は並列回路であり、解析的に合成抵抗を得る ことができる。以上の処理を一般化すると式(13)が得られ、本式を $n=0$ まで繰り返して適用寸れば全体の合成抵抗 $R_{c m b}=R_{c m b, 0}$ となる。 この合成抵抗を用いれば回路の根本での差圧が計算でき、上記の手 順を逆に繰り返せば、各流路の水量が計算できる。

$$
R_{c m b, n}=R_{s p, n}+\frac{1}{\left(\sqrt{\frac{1}{R_{c m b, n+1}}}+\sqrt{\frac{1}{R_{n}}}\right)^{2}}+R_{r t, n}
$$

\section{2 オブジェクト指向言語による実装}

オブジェクト指向言語である C\#を用いて上記の機能を実装した 結果を Table 1 に示す注3)。1 5 行は Fig.1 の抽象回路網を表現するイ ンターフェースであり、3 行および 4 行のメソッドは前記の機能要 求 1）および2）である。7 24 行と 26 60 行はそれぞれ Fig.2 の直列 回路と Fig.3 の並列回路を表すクラスであり、抽象回路網インター フェースを実装する。並列回路のコンストラクタ（32 行）では具体 的なクラスではなく、インターフェースを用いて各並列流路を初期 化している。また、47 59 行の必要最小差圧計算においてもインタ ーフェースを用いて式(10) (12)に相当する計算を行っている。この ため、60 行に過ぎないソースコードの量で、任意の深さの複雑な入 れ子状の回路網モデルを容易に構築することができる注 4)。本プログ ラムを用いて階層型の回路網モデルを構築する方法については、具 体例をもとに次章で示す。

Table 1 C\# source code for circuit models

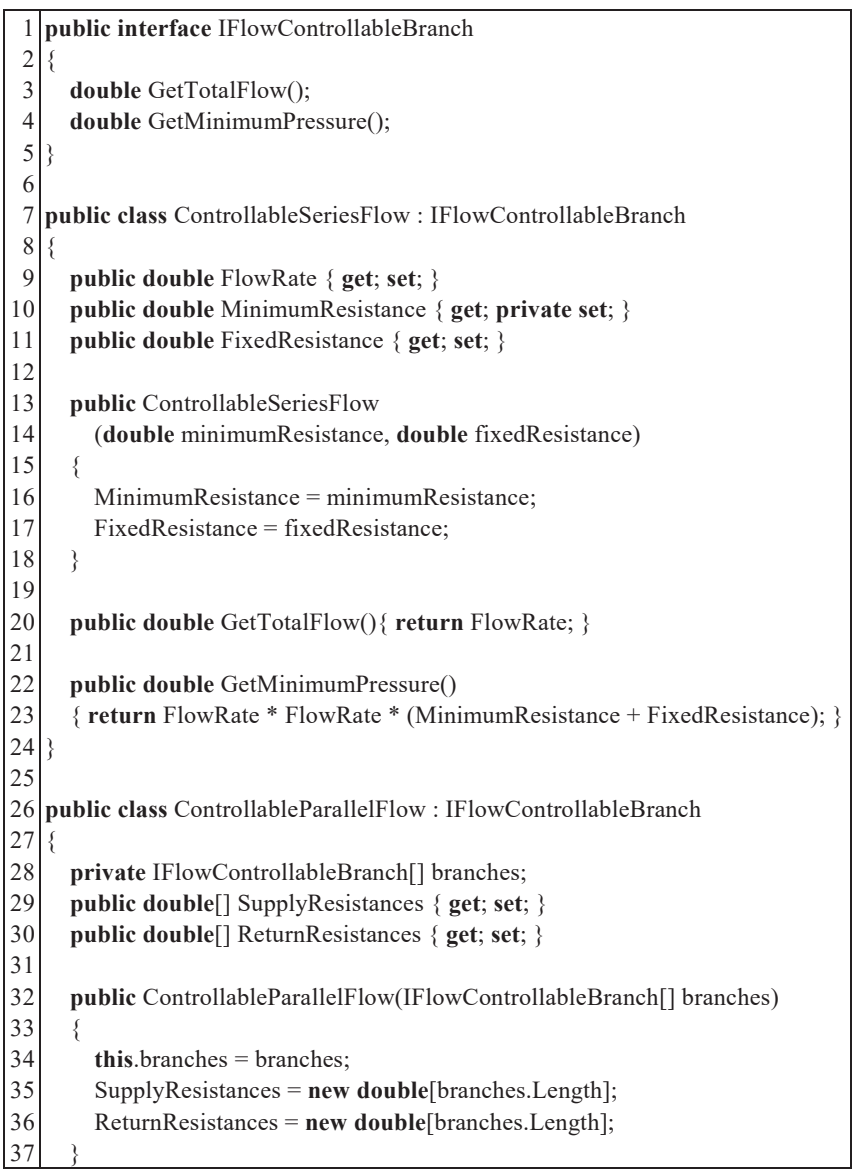




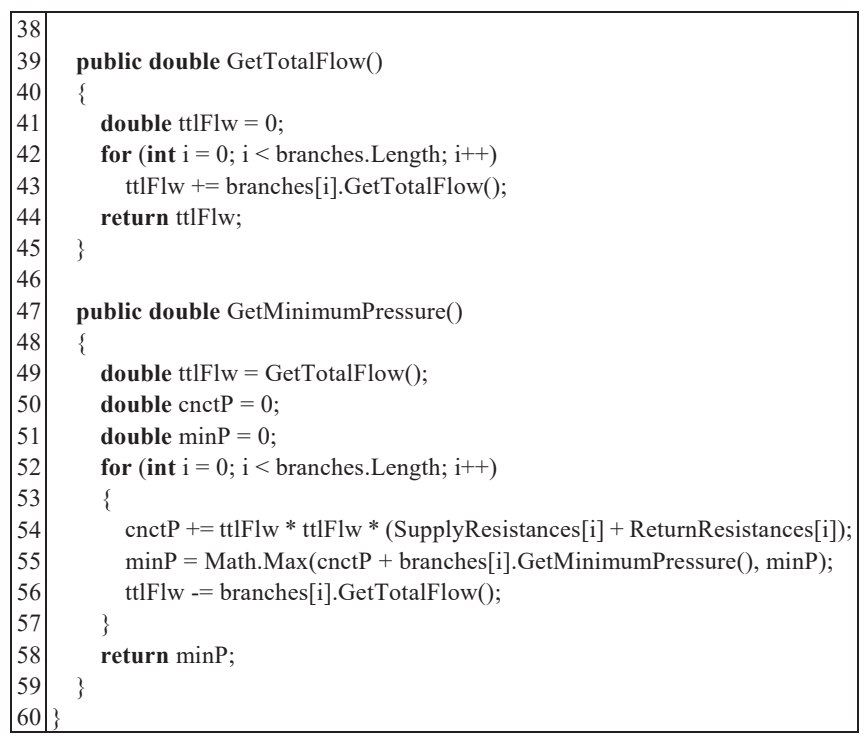

\section{4. 計算対象の建物}

\section{1 建築とシステムの概要}

計算対象の建物は「SHASE-G 1008-2016 建物エネルギーシミュレ ーションツールの評価手法に関するガイドライン ${ }^{12} 」$ に記載の建物 とした ${ }^{\text {注 }}$ 。基準階平面を Fig.4 に示す。ガイドラインに従い、1 階 は別系統で処理するものとみなし、2 7 階の 6 層を計算対象とした。 階高は $4.0 \mathrm{~m}$ 、天井高は $2.7 \mathrm{~m}$ 、空高は $1.4 \mathrm{~m}$ である。事務室は各階 で北側と南側に分かれている。図示の通り、外周部から $5 \mathrm{~m}$ の範囲 をペリメータゾーンとし、インテリアとペリメータで別系統の空調 機が負荷を処理する。往還ヘッダ $\left(\mathrm{HD}_{\mathrm{s}}, \mathrm{HD}_{\mathrm{r}}\right)$ 以降の冷水と温水の 配管系統図を Fig.5 に示寸。廊下と便所にファンコイルユニットが 配置されているが、これらの共用部は別系統として検討対象外とし た。AHU-n-1, 2, 3, 4 はそれぞれ北側ペリメータ、北側インテリア、 南側ペリメータ、南側インテリア、である。

\section{2 モデル化}

空調機 (および付属する器具)、空調機の流量調整のための二方弁、 竪配管、の 3 つの抵抗をモデル化する。Fig.5 を回路網で表現すると Fig.6 となる。 $R_{v l v, n, m}$ は $n$ 階の $m$ 番目の制御用二方弁の抵抗、 $R_{c o i l, m}$ は $m$ 番目の空調機の抵抗である。 $R_{p i p e, n}$ は $n$ 階から $n+1$ 階までの竪配管 の抵抗である。2 6 階の竪管の圧力損失は同じ值と寸るが、7 階は屋 上階機械置場までの圧力損失を加算する。

この回路は 3 段階の階層構造で表現できる。1 段階目は各階の 1 つの空調機回路（図の点線）であり、Fig.2 の直列回路モデルで表現 する。ただし $R_{f i x}=R_{c o i l, m 、} R_{c t r l}=R_{v l, n, m}$ である。2 段階目は、これらの 空調機回路を 4 組、並列に並べた各階の並列回路（図の長点線）で あり、Fig.3 の並列回路で表現する。ただし $R_{s p, n}=R_{r t, n}=0$ である。3 段階目は各階の並列回路をさらに 6 層並列に並べた建物の回路（図 の二点鎖線) であり、Fig.3 の並列回路で表現する。ただし $R_{s p, n}=R_{r t, n}$ $=R_{\text {pipe,7-n }}$ である。

Table 2 に冷温水回路の設計条件を示す。各階の空調機の仕椂は同 一とした。現実には最上階は屋上からの貫流熱負荷により、他階よ りもやや大きめの空調機器容量になるが、計算の簡略化のため、7 階 の上も 8 階が存在するものとみなして、この影響は考慮外とした。 これらの設計条件をもとに抵抗係数を推定した結果を Table 3 に示

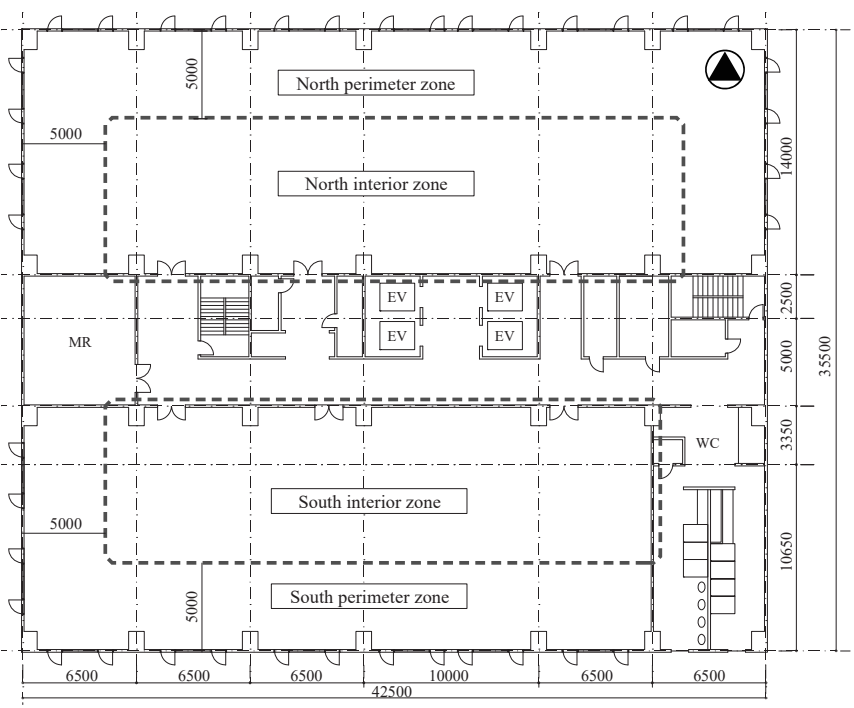

Fig.4 Plan of office building

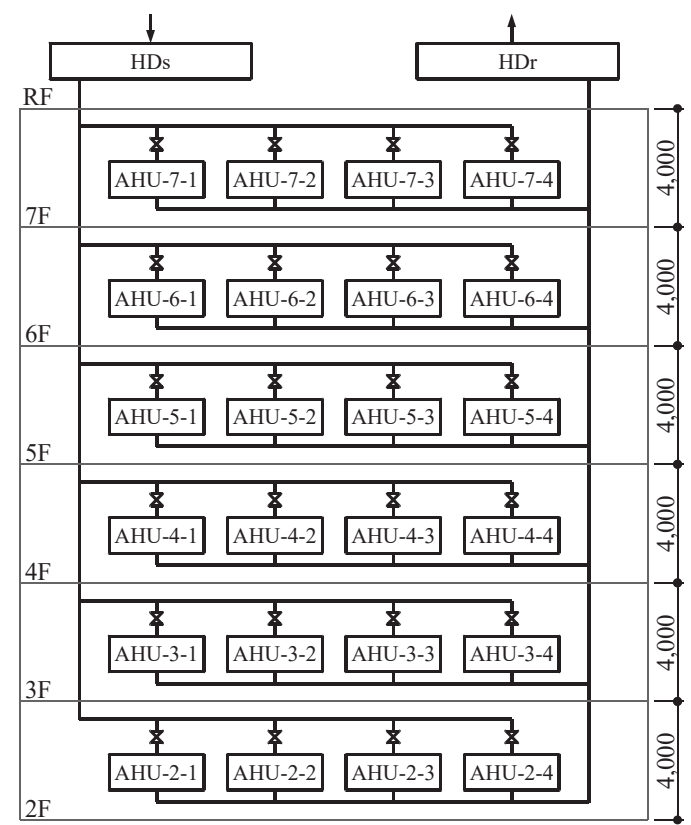

Fig.5 Heating and chilled water pipe system

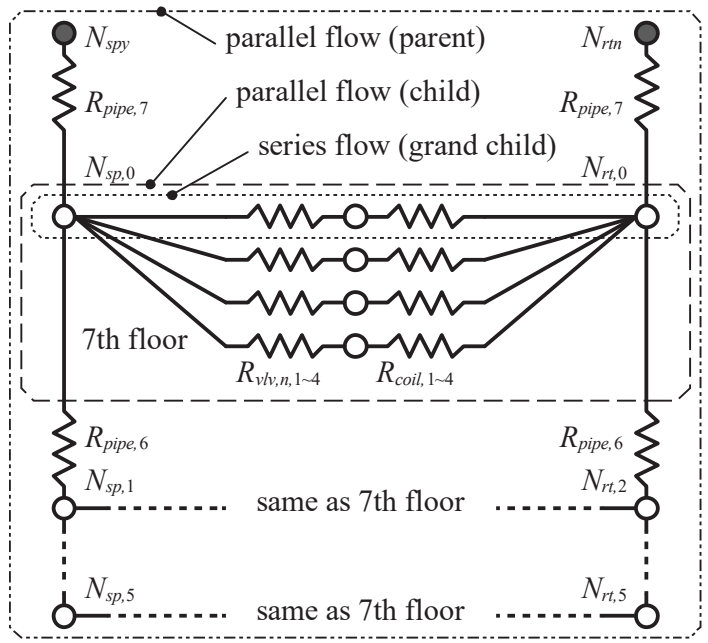

Fig.6 Circuit of water pipe network 
す。空調機の抵抗係数 $\left(R_{c o i l, m}\right)$ は設計条件における流量と圧力の関 係から求める。 $R_{V l v, n, m_{-} \text {op }}$ は制御用二方弁の全開時の抵抗係数であり、 各空調機の設計流量と全開時の圧力損失 $(5 \mathrm{kPa})$ から求める。運用 時には、負荷が最大となる流路以外の流路に関しては、二方弁を閉 じて水量を減少させるため、抵抗係数は全開時の抵抗係数よりも大 きい值となる。各空調機の水量を合算していけばす心゙ての堅管の水 量が求まるため、これと堅管の圧力損失 $(5 \mathrm{kPa})$ から各々の配管の 抵抗係数 $\left(R_{p i p e, n}\right)$ を求める。ただし最上階に関しては機械置場まで の抵抗を含むため、設計条件におけるポンプの出入口圧力差 $(200$ $\mathrm{kPa} ）$ と一致するように逆算する。

\section{Table 2 Design condition}

\begin{tabular}{l|l}
\hline Pump inlet / outlet pressure difference under design conditions & $200 \mathrm{kPa}$ \\
\hline Presure drop at
\end{tabular} \begin{tabular}{l|r}
\hline Pressure drop at vertical pipe ( $\triangle P$ at $R_{p i p e, n}$ ) & $5 \mathrm{kPa}$ \\
\hline
\end{tabular} \begin{tabular}{|l|c}
\hline Pressure drop at control valve of full open $\left(\Delta P\right.$ at $\left.R_{v l, n, m}\right)$ & $5 \mathrm{kPa}$ \\
\hline
\end{tabular}

\begin{tabular}{l|c|c}
\hline & chilled water & heating water \\
\hline $\begin{array}{l}\text { Pressure drop at single AHU } \\
\text { system }\left(\Delta P \text { at } R_{\text {coil }, m}\right)\end{array}$ & $60 \mathrm{kPa}$ & $40 \mathrm{kPa}$ \\
\hline Water flow at AHU- $n-1$ & $126.7 \mathrm{~L} / \mathrm{min}$ & $104.9 \mathrm{~L} / \mathrm{min}$ \\
\hline Water flow at AHU- $n-2$ & $111.2 \mathrm{~L} / \mathrm{min}$ & $92.9 \mathrm{~L} / \mathrm{min}$ \\
\hline Water flow at AHU- $n-3$ & $88.0 \mathrm{~L} / \mathrm{min}$ & $92.6 \mathrm{~L} / \mathrm{min}$ \\
\hline Water flow at AHU- $n-4$ & $103.5 \mathrm{~L} / \mathrm{min}$ & $86.0 \mathrm{~L} / \mathrm{min}$ \\
\hline
\end{tabular}

Table 3 Resistance coefficients

\begin{tabular}{|c|c|c|c|c|c|c|}
\hline & $R_{p i p e, 2}$ & $R_{p i p e, 3}$ & $R_{p i p e, 4}$ & $R_{p i p e, 5}$ & $R_{p i p e, 6}$ & $R_{p i p e, 7}$ \\
\hline cooling & $9.761 \times 10^{4}$ & $2.440 \times 10^{4}$ & $1.085 \times 10^{4}$ & $6.100 \times 10^{3}$ & $3.904 \times 10^{3}$ & $2.305 \times 10^{4}$ \\
\hline heating & $1.271 \times 10^{5}$ & $3.176 \times 10^{4}$ & $1.412 \times 10^{4}$ & $7.941 \times 10^{3}$ & $5.082 \times 10^{3}$ & $3.706 \times 10^{4}$ \\
\hline & & & $m=0$ & $m=1$ & $m=2$ & $m=3$ \\
\hline \multirow{2}{*}{ cooling } & \multicolumn{2}{|c|}{$\begin{array}{l}R_{v l v, n, m \text { op }} \\
\end{array}$} & $1.121 \times 10^{6}$ & $1.455 \times 10^{6}$ & $2.324 \times 10^{6}$ & $1.681 \times 10^{6}$ \\
\hline & \multicolumn{2}{|c|}{$R_{\text {coil, } m}$} & $1.345 \times 10^{7}$ & $1.746 \times 10^{7}$ & $2.789 \times 10^{7}$ & $2.017 \times 10^{7}$ \\
\hline \multirow{2}{*}{ heating } & \multicolumn{2}{|c|}{$R_{v l_{2}, n, m \text { op }}$} & $1.635 \times 10^{6}$ & $2.087 \times 10^{6}$ & $2.099 \times 10^{6}$ & $2.434 \times 10^{6}$ \\
\hline & \multicolumn{2}{|c|}{$R_{\text {coil }, m}$} & $1.308 \times 10^{7}$ & $1.669 \times 10^{7}$ & $1.680 \times 10^{7}$ & $1.947 \times 10^{7}$ \\
\hline
\end{tabular}

\section{3 負荷の偏在と必要水圧の計算例}

Table 1 のクラスを用いて、具体的に Fig.5 および Fig.6 の回路網の 必要差圧を計算するプログラムを Table 4 に示す。7 9 行で各空調機 および制御弁による直列回路をモデル化し、10 行で 4 台の空調機の 並列回路をモデル化する。5 11 行の繰り返しで 6 層分の並列回路を 作り、12 行で 6 層の並列回路を組み合わせてモデル化する。ただし、 配列 rVlvC, rCCoil, rPipeC にはそれぞれ Table 3 に示した抵抗係数が 予め代入されているものとする。16 行に示すように各流路に必要水 量を設定した後に、GetMinimumPressureメソッド (18 行)を呼べば、 入れ子状の回路網モデルのメソッドが再帰的に呼び出され、全体の 必要差圧が算出される。

Table 4 のプログラムを用いて冷水回路全体の流量比と必要差圧 比の関係を計算した結果を Fig.7 に示寸。負荷の偏在の影響を確認 するため、2つの計算を行った。1つ目は、すべての空調機の負荷率 が等しく減少する場合 (均一負荷)であり、2つ目は、往還ヘッダか らみて最近傍の空調機から順に負荷が減少していく場合（不均一負 荷) である。後者は、最遠端の空調機の負荷率が 100\%を維持し続け る場合であり、必要差圧が最も減少しづらい。

Fig.7 の点線に示すように、均一負荷の場合には、必要差圧は流量 の二乗に比例して速やかに減少する。一方で、不均一負荷の場合に
は最遠端の空調機に送水するために必要な差圧がなかなか減少しな いため、Fig.7の実線に示すように、全体の水量比が減少しても必要 差圧は減少しづらい。二次側配管抵抗が水量の一次式または二次式 で表現できると仮定する簡易モデルでは、このような負荷偏在によ る必要差圧の違いを全く評価できない。ポンプ動力は差圧に比例す るため、この誤差の大きさはそのまま比例的に消費電力の誤差に影 響を与える。ただし、本例の不均一負荷は最も必要差圧が大きくな る場合であり、現実の建物の多くの時間では、本例の均一負荷と不 均一負荷の間で運転が行われる。従って、このような負荷の偏在を 無視することで生じる、消費エネルギー予測值の誤差の大きさを知 るためには、負荷の偏在の発生頻度を組み合わせて計算を行う必要 がある。そこで次章では、期間熱負荷計算を行うことで、負荷偏在 の発生頻度を予測する。

Table 4 C\# source code of solving chilled water network
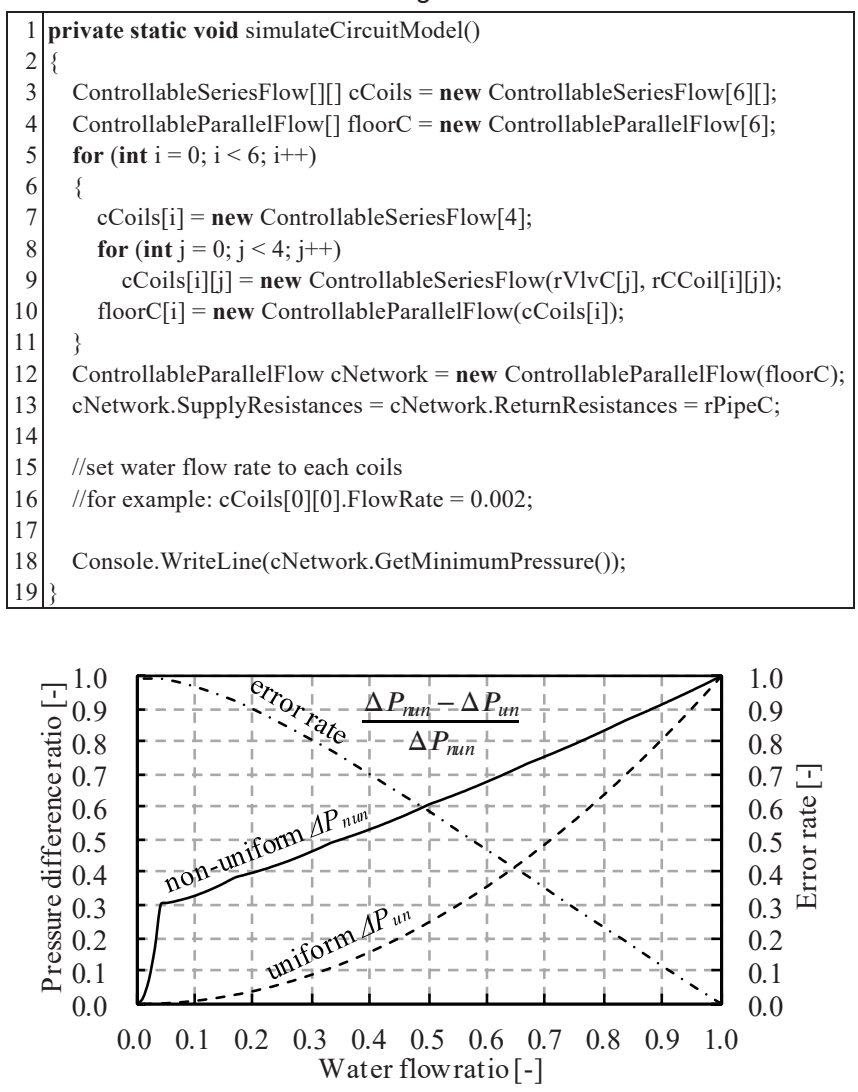

Fig.7 Water flow ratio and pressure difference ratio

\section{5. 期間シミュレーションによる評価}

\section{1 各階で運用が同一の場合}

Fig.4 に示した建築について年間熱負荷計算を行った。テナント の内部発熱スケジュールや空調の起動停止時刻などは基本的にガイ ドライン $\left.{ }^{12}\right)$ に記載の通りとしたが、 $4,5,10,11$ 月は冷房期間に変更 した。ガイドラインの通りに空調を停止させると、室温が過剩に上 昇する日があるためである。従って、階ごとの負荷は全く同じであ り、本計算で考慮する負荷の偏在は、南北による負荷傾向の違いと インテリアおよびペリメータのゾーンによる負荷傾向の違いである。 年間負荷計算結果をもとに、時刻別に冷水と温水の必要流量を計 
算し、前章で開発した回路網モデルを用いて二次ポンプの運転点を 計算した結果を Fig.8 に示す。図中の一点鎖線は二次側配管抵抗が 式(6)のように線形で表現できると仮定した場合である。同様に点線 は式(4)のように二次式で表現できると仮定した場合である。本研究 で開発した詳細な回路網モデルによる出力の多くは、これらの線に 挟まれていることがわかる。必要差圧は高負荷域では線形に減少し、 負荷が下がると非線形に減少している。また、冷水回路と温水回路 では温水回路の方が必要差圧が減少しづらいことがわかる。これは 暖房の方が空調機ごとの負荷の偏在が生じやすく、高負荷な空調機 の流路が残りやすいためである。南北のインテリア系統の空調機で ある AHU- $n-2$ と AHU- $n-4$ について、同時刻の流量比の関係を Fig.9 に示す。ばらつきは温水の方が大きいことがわかる。

運転点をもとに、年間の二次ポンプの水動力量を計算した注6)。詳 細モデルの計算結果を $100 \%$ とした場合の、従来の簡易モデルによ る計算結果の比率を Table 5 に示す。Simple model A は流量と二次側 抵抗が線形と仮定したもの、Simple model B は水量の二乗に比例す ると仮定したものである。簡易モデルを用いた場合には、年間では 30 60\%の誤差が生じることがわかる。 Simple modelC は、二次側抵 抗が水量の 1.5 乗に比例すると仮定したものである。理論的な根拠 は無いが、誤差は10\%未満に抑えられる。

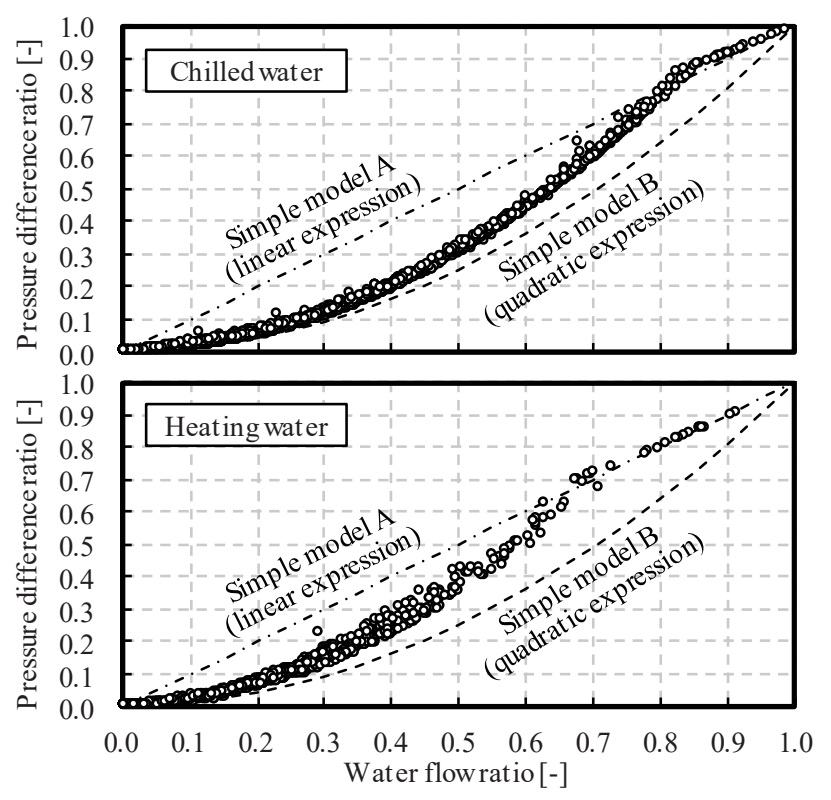

Fig.8 Water flow ratio and pressure difference ratio (Annual simulation, Fixed tenant model)

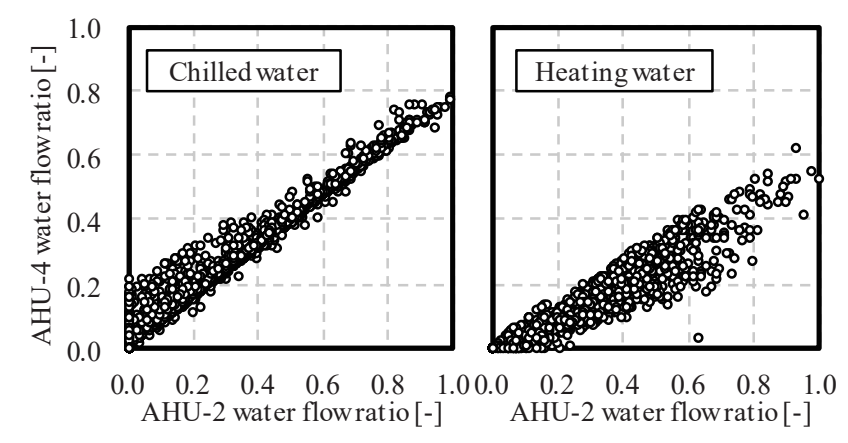

Fig.9 Water flow ratio of AHU-2 and AHU-4
Table 5 Hydraulic power ratio (Fixed tenant model)

\begin{tabular}{l|c|c}
\hline & Chilled water & Heating water \\
\hline \hline Detailed model & $100 \%$ & $100 \%$ \\
\hline Simple model A (linear expression) & $140 \%$ & $158 \%$ \\
\hline Simple model B (quadratic expression) & $82 \%$ & $69 \%$ \\
\hline Simple model C (1.5 $5^{\text {th }}$ power of the flow) & $105 \%$ & $101 \%$ \\
\hline
\end{tabular}

\section{2 各階で運用が異なる場合}

前節の検討では、南北および空調ゾーンの負荷の違いは考慮した が、各階の負荷は同一とした。自社ビルの場合にはこのような前提 であっても現実との乘離は少ないと予想されるが、テナントビルの 場合には、階ごとに負荷傾向が異なる可能性が高い。そこで既報 ${ }^{13)}$ において開発した確率的テナントモデルを用いることで、テナント の違いも反映した熱負荷計算を行った。各階の南北で別のテナント を想定し、全部で 12 の異なるテナントが入居する想定とした。

本モデルは、テナントの業種にもとづいて、男女比や年齢構成、 執務者数を確率的に発生させ、さらに一人一人の執務者行動を計算 することで時刻別の人員密度を確率的に求めるモデルである。人体 負荷は各時刻の滞在人数にもとづいて計算を行い、照明負荷率 $r_{l g t}[-]$ およびコンセント負荷率 $r_{p l g}[-]$ は、滞在者率 $r_{o c c}$ [-]を用いて式(14)お よび式(15)で計算を行った。ただし滞在者率が 0 の場合には $r_{l g t}=0$ とした。また、空調はコアタイム（8:00 18:00）を除く時間帯であっ ても、テナント区画内に執務者が存在する場合には稼働することと した。従って、早朝出勤、残業、休日出勤などがあった場合に、そ の一部のテナントのみが空調を要求するという状況が再現できる。

$r_{l g t}=0.8+0.2 r_{o c c}$

$r_{p l g}=0.25+0.75 r_{o c c}$

テナントを確率的に発生させ、1,000 回の計算を行った。1 回の年 間計算にもとづく二次ポンプの運転点の計算例を Fig.10 に示す。 各々のテナントでピーク負荷の時期が一致しないため、Fig. 8 に比較 すると高負荷の運転は減少する。一方、一部のテナントの負荷のみ が不均一に大きいような低負荷運転が生じるため、低負荷時に Fig. 8 よりも大きな差圧が必要となる運転点が多く表れる。

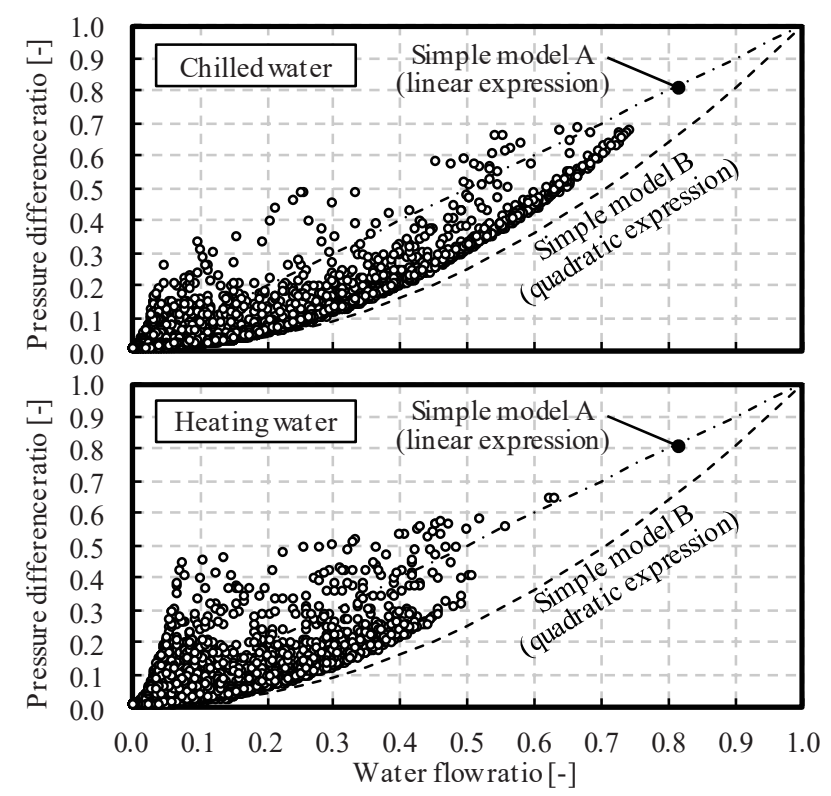

Fig.10 Water flow ratio and pressure difference ratio (Annual simulation, Random tenant model) 
1,000 回の計算結果をもとに二次ポンプの平均的な運転点を求め た。結果を Fig.11 に示す。平均的には Fig. 8 と概㸚同様の傾向を示 すが、Fig. 8 に比較すると、低負荷時の必要差圧がやや高まっている ことがわかる。これはFig.10に示したように、建物全体としては低 負荷であっても特定テナントが高負荷な場合に必要差圧が減少しな いような運転点が表れたためである。

Fig.11の平均的な運転点をもとに、年間の二次ポンプの水動力量 を計算した。詳細モデルの計算結果を $100 \%$ とした場合の、簡易モデ ルによる計算結果の比率を Table 6 に示す。簡易モデルの誤差は $30 \sim 60 \%$ 程度となった。

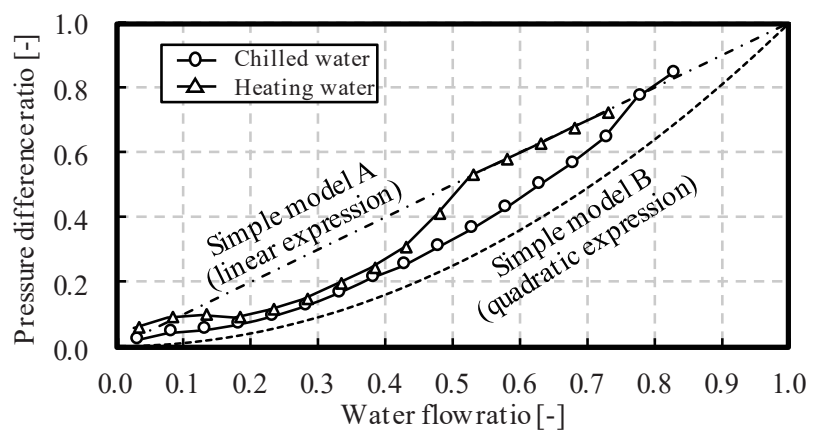

Fig.11 Water flow ratio and pressure difference ratio (Vaerage of 1,000 times simulatio)

Table 6 Hydraulic power ratio (Random tenant model)

\begin{tabular}{l|c|c}
\hline & Chilled water & Heating water \\
\hline \hline Detailed model & $100 \%$ & $100 \%$ \\
\hline Simple model A (linear expression) & $156 \%$ & $161 \%$ \\
\hline Simple model B (quadratic expression) & $72 \%$ & $49 \%$ \\
\hline Simple model C (1.5 $5^{\text {th }}$ power of the flow) & $104 \%$ & $87 \%$ \\
\hline
\end{tabular}

\section{6. 考察・結論}

本研究では、最小差圧変流量制御のエネルギー予測にあたり、配 管回路網の抵抗を流量の一次式ないしは二次式で近似するという従 来の簡易モデルを援用した場合に生じる誤差の大きさについて評価 を行った。このために収束計算が不要で任意の深さの並列回路網を 容易に構築できる新しい回路網モデルを開発した。

Fig.7 に示したように、負荷の偏在の状況によっては、従来の簡易 モデルでは数十\%の誤差が生じる可能性がある。この誤差の大きさ は、ポンプの PQ 特性やポンプ効率など、従来、多くのプログラム が精緻に表現しようとしてきた各種のパラメータによって左右され る誤差の大きさに劣らない。従って、仮に簡易モデルを用いるとし ても、抵抗曲線の設定は、二次側の負荷分布の特徴を捉えた上で適 切に行わなければならない。

方位別の違いや、ペリメータとインテリアゾーンの違いなど、従 来の多くの熱負荷計算プログラムが表現できる負荷傾向のみを考慮 した場合、ポンプの年間の運転点は Fig. 8 のようになった。従来の 簡易モデルで仮定されたように、二次側配管抵抗を流量の二次式で 表現すると過小なエネルギーとなり、一次式で表現すると過大なエ ネルギーとなる。本研究で開発した詳細モデルの計算結果を基準に おくと、年間での誤差は 30 60\%に達する。本研究の詳細モデルの出 力の多くは、上記の 2 つの抵抗曲線に挟まれており、二次側抵抗が
流量の 1.5 乗に比例すると仮定すれば、誤差は $10 \%$ 未満となった。 ただし、本研究の計算対象の冷温水回路網は比較的単純であり、多 くの横引配管や合流と分岐が繰り返される複雑な大規模建築におい てどのような傾向となるかは、別に確認する必要がある。

同一階のゾーンによる傾向の違いに加え、テナント活動による内 部発熱および空調運転時間のばらつきを、負荷計算に組み込んだ結 果、ポンプの年間の運転点は Fig.10のようになった。低負荷であっ ても特定のテナントの負荷のみが大きい場合、必要最小差圧が大き くなる運転点が表れた。この結果、Fig.11 に示される抵抗曲線が得 られ、Fig.8のようにテナントの不確実性を考慮しない場合と比較す ると低負荷において抵抗值が大きくなる傾向となった。現実のテナ ントオフィスビルでは、本モデルで表現できていない不確実性もあ るため、このような傾向は一層高まると予想される。従来の簡易モ デルと比較した場合の年間の誤差率は 30 60\%であり、二次側配管 抵抗が流量の 1.5 乗に比例すると仮定すれば誤差は $10 \%$ 未満となる。 本研究で計算対象とした制御方式は最小差圧変流量制御であり、 現在、ポンプの回転数制御方式として採用事例が多いと予想される、 末端差圧一定制御や推定末端差圧制御などの場合には、従来の簡易 モデルを用いたとしてもここまで大きな誤差は生じない。しかし、 将来、設備システム内の情報が、より精緻に観測されることが一般 的になれば、エネルギー消費量が最小化する最小差圧変流量制御が 主流になる可能性が高く、誤差の存在は無視し難いものになると予 想される。

誤差を解消寸るための方法としては主に 2 つると考える。1つ は従来の簡易モデルを用いつつ、流量の指数の大きさで抵抗特性を 調整する方法である。本研究の計算例に限れば 1.5 乗に比例すると 仮定寸れば誤差は $10 \%$ 未満となった。しかし現実には、この值は二 次側回路網の構造や負荷需要によって変化すると予想できるため、 この方法を取るのであれば二次側回路の特徴から指数の值を予想す る式や図表を作成する必要がある。もう1つの方法は、本研究で示 したように、複雑な配管回路網を直接にモデル化してしまう方法で ある。従来、この方法は、収束計算が必要になることと、モデル化 （モデル構築とパラメータ推定）が煩雑であることが原因となり敬 遠されてきた。しかし、本研究の方法を用いれば問題は解析的に解 け、また、階層的な構造であってもモデル構築の難度はほとんど変 わらない。煩雑なパラメータ推定作業が唯一の問題として残るが、

これは BIM （Building Information Modeling）技術の進展により解消 される可能性がある。個別の配管や器具の抵抗值は古くから解析的 な計算方法が確立しており、このような計算式に設定すべき配管長、 配管径、素材、などの情報は、将来的には BIM により半自動的に付 与できる可能性が高いためである。従って、誤差解消の方法として は、後者が有力であろうと予想する。

\section{謝辞}

本研究は JSPS 科研費 JP16K18198（建築設備システムの省エネ化投 資のリスク評価を可能にする確率モデルの開発) および JP18K04462 （建築の省エネ化投資の不確実性を反映した経済性評価）の助成を受 けたものです。記して謝意を表します。 


\begin{tabular}{|c|c|c|c|c|}
\hline \multicolumn{5}{|c|}{ 【記号一覧】 } \\
\hline$c \rho$ & : 体積比熱 & & & {$\left[\mathrm{kJ} /\left(\mathrm{m}^{3} \cdot\right]\right.$} \\
\hline$N$ & : 節点 & & & \\
\hline$P_{0}$ & : 実揚程 & & & \\
\hline$Q_{\text {scd }}$ & : 二次側負荷 & & & {$[\mathrm{k}$} \\
\hline$R$ & : 抵抗係数 & & & {$\left[\mathrm{kPa} /\left(\mathrm{m}^{3} / \mathrm{s}\right)\right.$} \\
\hline$r_{l g t}$ & ：照明発熱負荷率 & & & \\
\hline$r_{o c c}$ & ：人体発熱負荷率 & & & \\
\hline$r_{p l g}$ & : コンセント発熱負荷率 & & & \\
\hline$T$ & : 温度 & & & \\
\hline V & : 水量 & & & \\
\hline$W$ & : ポンプ消費電力 & & & \\
\hline$\Delta P$ & : 差圧 & & & \\
\hline$\eta_{p}$ & : ポンプ効率 & & & \\
\hline$\eta_{M}$ & : モーター効率 & & & \\
\hline$\eta_{I n v}$ & : インバータ効率 & & & \\
\hline \multicolumn{5}{|c|}{ Subscripts: } \\
\hline coil & : 空調機のコイル & nun & : 不均一 & （負荷偏在） \\
\hline$c m b$ & : 合成抵抗 & $o p$ & : 全開 & \\
\hline cnct & : 接続流路 & pipe & ：竪配管 & \\
\hline ctrl & : 制御用可変抵抗 & $r t$ & ：還 & \\
\hline fix & : 固定抵抗 & $s p$ & : 往 & \\
\hline$m$ & : 空調機番号 & $t t l$ & : 合計 & \\
\hline$N$ & : 定格 & $u n$ & : 均一 & \\
\hline$n$ & : 階数 & $w$ & : 水 & \\
\hline
\end{tabular}

1) Sato, F., Takesako, M., Kitamura, K., Yamashita, H., Sasaki, K., Ken-ichi, Y., and Nobe, T.: Study on Efficiency Improvement in VWV System by Minimum Differential Pressure Control, Trans. of the SHASE of Japan, No. 259, pp. 21-29, 2018.10 (in Japanese)

佐藤文秋, 竹迫雅史, 北村邦彦, 山下博幸, 佐々木邦治, 安田健一, 野部達 夫: 最小差圧変流量制御による搬送効率向上に関する研究, 空気調和・衛生 工学会論文集, No. 259, pp. 21-29, 2018.10

2) Standard simulation program for air conditioning system, HASP/ACSS/8502 program reference manual, Japanese association of building mechanical and electrical engineers, pp. 23-25, 1985 (in Japanese)

空調システム標準シミュレーションプログラム HASP/ACSS/8502 プログ ラム解説書, 日本建築設備士協会, pp. 23-25, 1985

3) Energy Plus version 8.9.0 documentation, Engineering Reference, Chapter 18.4 Pumps, U.S. Department of Energy, pp. 1278-1284, 2018

4) Tanaka, H., Niwa, H., Yoshinaga, M., Watanabe, T., et al.: Development of HVAC System Simulation for Life Cycle Energy Management, Part 8 Entire configuration of the Simulation Tool and Outline of Newly Developed Objects, Techinical Papers of Annual Meeting the SHASE of Japan, pp. 653-656, 2007 (in Japanese) 田中英紀, 丹羽英治, 吉永美香, 渡辺剛, 他: ライフサイクルエネルギーマ ネージメントのための空調システムシミュレーション開発, 第 8 報 シミ ユレーションツールの全体像と新規オブジェクトの開発概要, 空気調和・ 衛生工学会大会学術講演論文集, pp. 653-656, 2007

5) LCEM tool ver 3.03, Calculation algorithm of main object, Central heat source and air conditioning system, Ministry of Land, Infrastructure, Transport and Tourism, p. 2, Jan., 2011.1 (in Japanese)

LCEM ツール ver 3.03 主要オブジェクトの計算アルゴリズム 中央熱源空 調編, 国土交通省大臣官房官庁営繕部設備・環境課, p. 2, 2011.1

6) Shinagawa, K., Murakami, S., Ishino, H., Yanai, T., and Abe, H.: Study on Database Construction of Equipment Characteristics of Air Conditioning for Energy Simulation, Part1 - Database and Sensitivity Analysis of the Conveyance Apparatus, Trans. of the SHASE of Japan, No. 227, pp. 1-9, 2016.2 (in Japanese) 品川浩一, 村上周三, 石野久彌, 柳井崇, 阿部裕司: エネルギーシミュレー
ションのための機器特性データベースの構築に関する研究, 第 1 報 搬送機 器のデータベース概要と感度解析, 空気調和・衛生工学会論文集, No. 227, pp. 1-9, 2016.2

7) HVACSIM+ (J) User manual, Chapter 6.2 Water and air flow, pp. 33-94, 2001.1 (in Japanese) HVACSIM+ (J) ユーザマニュアル, 6.2 節 搬送系, pp. 33-94, 2001.1

8) Yahagi, K., and Yoshii, I.: Energy consumption through carrier powers, Trans. of the SHASE of Japan, No. 5, pp. 43-54, 1977.10 (in Japanese)

矢作和久, 吉井功: 搬送系の少エネルギ, 空気調和・衛生工学会論文集, No. 5, pp. 43-54, 1977.10

9) Okazaki, N., Mizutani, K., Iguchi, Y., and Satoh, H.: Study of variable speed pump's control method with heat source system's P-Q model. Part 1 Study of control method and confirm fundamental property by experiment, Trans. of the SHASE of Japan, No. 155, pp. 11-18, 2010.2 (in Japanese)

岡崎徳臣，水谷国男，井口泰男，佐藤秀幸：熱源システムのモデリングによ る可変速制御方法に関する研究：第 1 報-制御方法の検討と実験による基 本特性の確認, 空気調和・衛生工学会論文集, No. 155, pp. 11-18, 2010.2

10) Zhao, F., and Sumiyoshi, D.: Energy saving effect of integrated piping in building HVAC system, Trans. of the SHASE of Japan, No. 223, pp. 1-9, 2015.10 (in Japanese)

趙飛，住吉大輔：建築空調システムにおける統合配管の省エネルギー効果， 空気調和・衛生工学会論文集, No. 223, pp. 1-9, 2015.10

11) Zhao, F., and Sumiyoshi, D.: Energy saving effect of series connection pumps in a building HVAC system, Trans. of the SHASE of Japan, No. 230, pp. 9-19, 2016.5 (in Japanese)

趙飛, 住吉大輔: 建築空調システムにおけるポンプ直列配置の省エネルギ 一効果, 空気調和・衛生工学会論文集, No. 230, pp. 9-19, 2016.5

12) SHASE, SHASE-G, 1008-2016, Guideline of Test Procedure for the Evaluation of Building Energy Simulation Tool (in Japanese) 空気調和・衛生工学会, SHASE-G 1008-2016, 建物エネルギーシミュレーシ ヨンツールの評価手法に関するガイドライン, 2016

13) Togashi, E.: Effect of energy conservation technology on value of real estate. Part 4 Development of stochastic model of tenant characteristics, Trans. of the SHASE of Japan, Vol. 43, No. 253, pp. 31-37, 2018.4 (in Japanese)

富樫英介：設備システムの省エネルギー化が不動産価值に与える影響の定 量的評価方法に関する研究：第 4 報-テナント属性および建物運用の確率 モデルの開発, 空気調和・衛生工学会論文集, Vol. 43, No. 253, pp. 31-37, 2018.4

14) Matsumoto, T., and Tazaki, S.: Kankyou Kyousei Sedai no Kenchiku Setsubi no Jidou Seigyo Nyumon (Introduction to Automatic Control of Building Facilities for Environmental Symbiosis Generation), Gijutu Shoin, p.155, 2007 (in Japanese) 松元忠雄, 田崎茂: 環境共生世代の建築設備の自動制御入門, 技術書院, p. 155,2007

注

注 1）極小流量時にも解の存在を保証するためである。

注 2）す心゙ての二方弁の開度情報を収集し、最大開度となる系統が $100 \%$ を少 し下回るようにポンプの台数や回転数を下げていく方法。DDC 連携制御と も呼ばれる ${ }^{14)}$ 。

注 3）本研究の以降の検討では用いないため、3.1 節の後段で解説した差圧か ら水量を求める問題に関するソースコードは省略した。コードはすべて公 開(http://www.hvacsimulator.net)したため、詳細はコードを参照されたい。

注 4) オブジェクト指向言語の特徴をいかして、このような階層状のモデルを 組夕立てるためのコーディングパターンを composite pattern と呼ぶ。

注 5) 建物および設備仕様はガイドラインに準拠させたため、本報では概要の みを記載した。詳細はガイドラインを参照されたい。

注 6) 水量と必要圧力の関係から具体的なポンプの運転点を知るためには、下 限回転数を考慮した上でポンプの PQ 特性を設定する必要がある。また、 消費電力量を求めるためには、ポンプ効率、モーター効率、インバータ効 率の設定も必要となり、これらの設定の如何によっては結果が変動するた め、ここでは単純に水量と必要圧力を乗じた水動力で誤差の大きさを評価 した。 


\title{
PREDICTION OF ENERGY CONSUMPTION IN VWV SYSTEM BY MINIMUM DIFFERENTIAL PRESSURE CONTROL
}

\author{
Eisuke TOGASHI*1 \\ ${ }^{* 1}$ Assoc. Prof., Dept. of Architecture, School of Architecture, Kogakuin University, Dr.Eng.
}

In this study, the error of a conventional simple pump model that approximates the resistance of a piping network using a linear or quadratic equation of flow rate was evaluated. For this purpose, a new water circuit model that can easily construct a parallel flow network of free depth without convergence calculation was developed. As shown in Fig.7, due to a non-uniform distribution of load, it is possible that an error of several tenths in energy prediction should occur in the conventional simple pump model. The magnitude of this error could be higher than the magnitude of the error that is influenced by various parameters, such as the pressure and flow rates of the pump and the pump efficiency, which many previous traditional programs have attempted to precisely represent. Therefore, the resistance curve must be set appropriately by capturing the load distribution characteristics of the HVAC (Heating, Ventilation, and Air Conditioning) system. By considering the heat load characteristics that many conventional heat load calculation programs can express, such as the difference in orientation or the difference between the perimeter and the interior zone, the annual operating point of the pump is predicted, as shown in Fig.8. In the conventional simple pump model, if the resistance of the water pipe network is represented by a quadratic equation of flow rate, the energy prediction obtained is too small; if the resistance is expressed by a linear equation, the energy prediction obtained is excessive. Compared with the calculation result of the detailed water circuit model developed in this study, the annual error rate of conventional simple pump model was 30 60\%, which is not small. For the pump model considered in this study, many operating points were lined up between the two assumed resistance curves represented by linear and quadratic equations. If the resistance of the water pipe network is proportional to the $1.5^{\text {th }}$ power of the flow rate, the error is less than $10 \%$. The chilled and heating water network to be calculated in this study is not complex. It must be confirmed whether characteristic of being proportional to the $1.5^{\text {th }}$ power of the flow rate can also be applied to a complex largescale building, where there is an extensive merging and branching of pipes. As a result of integrating the model for heat generation due to tenant activities, and the variations in air conditioning operation times, into the aforementioned heat load calculation model, the annual operation point of the pump changed, as shown in Fig.10. Even when the load on a building as a whole was low, the required minimum differential pressure was high because the load on a specific tenant was large. Thus, the resistance curve shown in Fig.11 was obtained. Compared to the results of the simulation where the uncertainty of tenants was not considered (Fig.8), the resistance, according to solid line in Fig.11, tended to increase at low loads. In actual tenant office buildings, there are uncertainties that cannot be expressed in the model; therefore, the tendency to increase in case of low load is expected to further increase.

（2018 年 8 月 29 日原稿受理, 2018 年 11 月 19 日採用決定 